\title{
NORMIZACIJA POKAZATELJA ONEČIŠĆENJA POVRŠINSKIH I PODZEMNIH VODA ALGORITMIMA NEIZRAZITE LOGIKE
}

\begin{abstract}
U radu je predložen pristup izradi normi za pokazatelje onečišćenja podzemnih $i$ površinskih voda primjenom algoritama neizrazite logike. Polazeći od osnovnog hibridnog modela praćenja onečišćenja okoliša, koji se sastoji od determinističkog dijela, kojim se opisuju mehanizmi djelovanja tvari i dijela kojim se opisuje neizvjesnost u praćenju pokazatelja onečišćenja, dosljednom primjenom koncepata neizrazite logike izvedena su rješenja za uvođenje i primjenu neizrazitih normi te praćenje emisija u vode i stanja vodnog okoliša.
\end{abstract}

\section{UVOD}

Kod praćenja pokazatelja onečišćenja u okolišu polazi se, prema Vic BARNETT i Tony O'HAGAN, Standard setting problems-The statistical approach for handling uncertainty and variation, Chapman\&Hall, London, 1997, 44.-45., od hibridnog modela koji povezuju odziv (utjecaj onečišćenja) sa svojstvom (koncentracija tvari) i koji se sastoji od determinističkog i statističkog dijela (1):

$$
Y=f(X, \beta)+E
$$

gdje je:

- $f(X, \beta)$ - deterministički dio modela koji povezuje svojstvo i mehanističke parametre modela $\beta$,

- X - pokazatelj onečišćenja (koncentracija tvari) kao varijabla modela,

- $\beta$ - mehanistički (fizikalni) parametar modela,

- E - slučajna pogrješka odziva (statistički dio modela). 
U modelima odziv - svojstvo za odziv (veličina determinističkog člana modela odziva $f(X, \beta))$ u toksikologiji okoliša, česta je mjera argumenta „,kumulativna smrtnost" koja se odnosi na različite testne organizme, kao i druge mjerljive promjene na testnim organizmima, David A. WRIGHT i Pamela WELLBOURN, Environmental toxicology, Cambridge university press, Cambridge, 2002., 28., 60.

Za primjenu u neizrazitoj logici, izraz (1) potrebno je prikazati u neizrazitom obliku kao (2):

$$
\tilde{Y}=\tilde{f}(X, \beta)+\tilde{E}
$$

gdje oznaka označava neizrazitu varijantu gore navedenih veličina, koja u općem slučaju predstavlja neizraziti skup ili broj. Razlika između klasične (dvovrijednosne) logike i neizrazite logike kao jedne od viševrijednosnih logika, je u definiranju vrijednosti istinitosti koja se u neizrazitoj logici nalazi u intervalu [0,1], dok kod klasične to može biti samo 1 ili 0 . U neizrazitoj logici također se barata pojmom funkcija udjela za vrijednosti istinitosti u opisu pripadnosti skupovima. (Dalje se upućuje na odgovarajuću literaturu u kojima su pojmovi neizrazite logike detaljno razloženi, npr. Timothy J. ROSS, Fuzzy logic with engineering applications, Mc.Graw-Hill, New-York, 1995, 2.-43. i 89.).

Za opći slučaj, deterministički dio modela može se napisati kao neizrazita veličina (3):

$$
\tilde{f}(X, \beta)=f(\tilde{X}, \tilde{\beta})
$$

gdje je:

$\tilde{\beta}$ - neizrazita veličina parametra modela,

$\tilde{X}$ - neizrazita veličina pokazatelja onečišćenja (varijabla modela).

Neizrazita veličina, npr. $\tilde{X}$ može se napisati dvočlano, kao $\tilde{X} \equiv(X, \mu(X))$, gdje je $\mu$ funkcija udjela od $X$.

Kod određivanja determinističkog člana modela odziv - svojstvo također se prethodno provodi statistička obrada empirijskih podataka kroz regresijsku analizu ili planiranje eksperimenata, usporedbu više testnih populacija, razlike u veličini uzorka i populacija, određene biološko-kemijske interakcije, usporedbu s većim populacijama D. A. WRIGHT, isto 38 , te veličina $\beta$ ima komponentu neizvjesnosti koja bi se mogla prikazati metodama neizrazite logike. Stoga, neizrazita veličina parametra modela $\tilde{\beta}$ u općem slučaju može biti neizraziti nelinearni operator koji povezuje svojstvo s odzivom i sadrži sve neizrazite članove (4):

$$
\tilde{\beta} \equiv \tilde{\beta}_{1} \cdot(\ldots)^{\tilde{n}}+\tilde{\beta}_{2} \cdot(\ldots)^{\tilde{n}-1} \ldots .+\tilde{\beta}_{n+1} \cdot(\ldots)^{\tilde{n}-n}
$$


gdje je:

$\widetilde{\beta_{n}}$ - neizraziti koeficijent operatora,

(...) - operatorski prostor,

$\tilde{n}$ - neizraziti eksponent.

Zbog praktičnih razloga, uzimajući manje zahtjevan matematički opis, u ovom će se radu razmatrati slučajevi kada članovi operatora $\beta$ nisu neizrazite veličine, te kao neizrazite veličine modela (2) ostaju $\tilde{X}$ i $\tilde{E}$ (5):

$$
\tilde{Y}=f(\tilde{X}, \beta)+\tilde{E}(5)
$$

S obzirom na pretpostavku da se fizikalni parametri modela $(\beta)$ mogu smatrati operatorom neizrazite varijable $\tilde{X}$, može se napisati (6):

$$
\tilde{Y}=\beta(\tilde{X})+\tilde{E}(6)
$$

Član modela (6), $\tilde{E}$, izvodi se kao neizrazita veličina iz razdiobe vjerojatnosti $E$ (pogrješka odziva), koji se može pripisati osnovnom modelu (1), i koja uobičajeno odražava pogrješke mjerenja i razlučivost metoda, primjenom transformacija kojima se razdiobe vjerojatnosti prevode $u$ razdiobe vjerodostojnosti ili mogućnosti događaja (engl. possibility distribution), koje su također neizrazite veličine. Te druge razdiobe izvode se iz teorije dokaza Dempster-Shafera, J. B. PARIS, The uncertain reasoner companion - A mathematical perspective, Cambridge university press, New York, 1994. 34.-51. Transformacija u razdiobu mogućnosti provodi se prema A. K. VERMA, A. SRIVIDIYA, R. S. PRABHU-GAONKAR, Fuzzy-reliability engineering-concepts and applications, Narosa, New Delhi, 2007., 113.-115., bijektivnim preslikavanjem $p \leftrightarrow \pi$, gdje je $p$ vjerojatnost, a $\pi$ neizrazita razdioba, izražena kao vrijednost funkcije udjela $\mathrm{u}$ intervalu [0,1]. Za transformaciju normalne (Gaussove) razdiobe $u$ razdiobu mogućnosti daje se, prema Willi-Hans STEEB, The nonlinear workbook, World scientific, New Jersey, 2005., 517., izraz (7):

$$
\pi(y)=\exp \left[\frac{-\left(y-y_{0}\right)^{2}}{\sigma^{2}}\right](7),
$$

gdje je:

$y \in Y$ - član razdiobe,

$y_{0}$ - srednja vrijednost razdiobe,

$\sigma^{2}$ - varijanca razdiobe,

$\pi(y)$ - funkcija neizrazite razdiobe (tj. funkcija udjela) za opći slučaj, a izvedive su transformacije i za ostale razdiobe. 
Općenito, uz pretpostavku da su poznate statističke razdiobe (ne nužno normalne) dovoljne za opisivanje pogrješke, može se napisati da je $\pi(y) \equiv \tilde{E}$. I za definiranje neizrazitog skupa pokazatelja praćenja $\tilde{X}$ može se, kao i za pogrješku, poći od statističke (najčešće normalne) razdiobe prikazane izrazom (8):

$$
\tilde{X}_{n}=\left(\pi\left(X \widehat{-x_{\text {norm }}}\right)\right)(8)
$$

gdje je:

$\pi$-transformacija statističke razdiobe $\left(X \widehat{-x_{\text {norm }}}\right) \mathrm{u}$ razdiobu neizrazitog tipa (razdioba mogućnosti),

$x_{\text {norm }}$ - vrijednost veličine $X$ prema kojoj se varijabla $X$ normalizira $\left(x_{\text {norm }} \in X\right)$.

Kod definiranja takve razdiobe može se normalizirati veličinu $X$ prema nekoj vrijednosti člana razdiobe rezultata. To može biti zadana (kontrolna) vrijednosti mjerenja. Primjer jedne takve razdiobe prikazan je na sl. 6 .

Osim statističke komponente neizvjesnosti iz (7) i (8), neizrazitim varijablama $\tilde{E} i$ $\tilde{X}$ mogu se pripisati i druge, kada sama statistička razdioba nije dovoljna za svrhu za koju se model radi. Za to postoje odgovarajuće tehnike, npr. povezivanje statističkog i neizrazitog člana, Simone SALICONE, Measurement uncertainity-An approach via the mathematical theory of evidence, Springer, New York, 2007.,125.- 194. Primjeri praćenja onečišćenja podzemnih voda primjenom neizrazite logike, različitim metodološkim pristupima koje omogućuje neizrazita logika, navode se u Robert V. DEMICO i George J. KLIRR, Fuzzy logic in geology, Elsevier Science Amsterdam, 2004., 156. - 180.

\section{ODREĐIVANJA I PRIMJENA NEIZRAZITIH NORMI}

Pitanju određivanja i primjene neizrazitih normi za praćenje emisija otpadnih voda i praćenja (monitoring) stanja površinskih voda, može se poći od postojećih normi, koje su donijete na razini Europske unije primjenom odgovarajućih shema, a u hrvatsko su zakonodavsto prenijete, kroz uredbe i pravilnike, u procesu pristupanja Hrvatske Europskoj uniji. Veličina $X$, pokazatelj onečišćenja (koncentracija tvari), je veličina koja se sada nalazi u propisima. Hrvatski propisi, koji reguliraju pitanje normi za pokazatelje onečišćenja površinskih voda su Pravilnik o graničnim vrijednostima emisija otpadnih voda, Pravilnik o izmjenama i dopunama pravilnika o graničnim vrijednostima emisija otpadnih voda, Uredba o standard kakvoće okoliša, Uredba o izmjenama i dopunama uredbe o standardu kakvoće voda, http:// voda.hr/hr/zakoni-propisi-zastita-voda-vodnog-okolisa.html (14. listopad 2015.). U njima se norme daju kao granične (dozvoljene) koncentracije za pojedine tvari, ili srodne skupine tvari, u obliku determinističkih i statističkih normi (50-i percentil ili 
srednje vrijednosti), a ovim posljednjima već se izražava neizvjesnosti koja se javlja kod praćenja emisija ili stanja okoliša.

\section{Način određivanja neizrazitih normi}

Metodologija određivanja normi u donošenju propisa Europske unije, koja uzima u obzir neizvjesnost, kroz osnovnu karakterizaciju rizika, opisana je u Peter CALOW, Controlling environmental risks from chemicals-Principles and practice, John Willey\&Sons, Chichester, 1997.,11.-31. Neizvjesnost se veličini (varijabli) $\tilde{X} u$ procesu izrade normi može pripisati u različitim fazama izrade, Isto, 26., koje su prikazane u tablici 1. za determinističke i statističke norme. Neizvjesnost se pripisuje i za djelovanje tvari i raspodjelu tvari. Mjesta pripisivanja neizvjesnosti označena su simbolima iz osnovnog modela praćenja (6).

Tablica 1. EU shema za određivanje normi - mjesta pripisivanja neizvjesnosti kod donošenja determinističke i statističke norme

\begin{tabular}{|c|c|}
\hline Raspodjela tvari u okolišu & Mehanizam djelovanja tvari \\
\hline Količina ispuštene tvari & Određivanje funkcije odziva, $E, \beta(.), Y$. \\
\hline & $\downarrow$ \\
\hline & Izbor faktora sigurnosti, $F$ \\
\hline$\downarrow$ & $\downarrow$ \\
\hline $\begin{array}{c}\text { Modeliranje raspodjele u okolišu } \\
\text { (predviđena koncentracije u okolišu } \hat{X} \\
\text { ili } \bar{X} \text { ) } \\
(\end{array}$ & $\begin{array}{l}\text { Vrijednost koncentracije odziva za koju } \\
\text { nema posljedica, uz primjenu faktora } \\
\text { sigurnosti,etobivena primjenom funk- } \\
\text { cije ekstrapolacije, kao } X\left(Y, \frac{1}{F}\right)\end{array}$ \\
\hline CB analiza & \\
\hline \multicolumn{2}{|c|}{$\begin{array}{l}\text { Usporedba predviđene koncentracije u okolišu i predviđene } \\
\text { koncentracije koja uzrokuje posljedice u okolišu } \\
\text { (kao kvocijent rizika }=\bar{X} / X\left(Y, \frac{1}{F}\right) \text { ) } \\
\text { te donošenja odluke o normi, kao } \mu(X)=1 \text { za determinističku } \\
\text { ili } \mu(\bar{X})=1 \text { za statističku normu }\end{array}$} \\
\hline
\end{tabular}


U tablici su dodatno: $\hat{X}$ raspodjela tvari u okolišu opisana statističkom razdiobom, $\bar{X}$ srednja vrijednost koncentracije u okolišu ili druga statistička mjera, $X\left(\frac{1}{F}, Y\right)$ funkcija računske ekstrapolacije primjenom faktora sigurnosti osnovnog modela $Y$ iz područka u kojem ima efekata (određeno eksperimentalno ili drugim podacima) do područja modela gdje ih nema, $F$ faktor sigurnosti, a $\mu$ funkcija udjela norme, kao pogodna zajednička mjera za determinističke, statističke i neizrazite norme.

Kod definiranja odgovarajuće funkcije ekstrapolacije može se napraviti razlika između tzv. NOEC koncepta određivanja referentnih veličina (engl. „no-observed effect concentration “) i i LOEC koncepta (eng. „lowest observed effect concentration“). NOEC se može opisati kao vrijednost koncentracije tvari kod koje nisu primijećene nikakve posljedice odziva, sl. 2. dok LOEC kao vrijednosti kod koje se primjećuje najmanja posljedica odziva, sl. 2. Osim njih, može se koristiti i veličina $L D_{50}$ (doza smrtnosti) test organizama kod 50-og percentila, što zahtjeva znatno veće faktore sigurnosti. Faktori sigurnosti koji se za norme preuzimaju iz ekotoksikologije mogu se podijeliti na faktore krajnje neizvjesnosti koji se određuju već unaprijed zadanim kriterijima i nisu povezani s osnovnim modelom, te na aplikativne faktore koji uzimaju u obzir modele na kojima će se primijeniti prema D. A. WRIGHT, n.dj. 510-511. Aplikativni faktori pogodniji su za daljnju razradu kroz neizrazite norme, zbog već prepoznatih mjesta pripisivanja funkcija udjela. (Primjena aplikativnih faktora pretpostavljena je i u tabl. 1. i 2.).

Neizvjesnost se za djelovanje tvari pripisuje preko faktora sigurnosti te raspodjele tvari u okolišu, kao statistička razdioba ili već srednja vrijednost $\bar{X}$. Determinističke norme dobivene ovim načinom nazivaju se referentnim normama, izražene kao referentne koncentracije (RfC), zbog primjene faktora sigurnosti na vrijednosti empirijskog testa, V. BARNETT i T. O/HAGAN, n.dj. 72.

Donošenje odluke o normi prema shemi iz tabl. 1. temelji se na usporedbi predviđenih koncentracija u okolišu s predviđenom koncentracijom tvari (dozom) koja uzrokuje posljedice. Primjena neizrazite logike na osnovnu shemu iz tabl. 1. prikazana je u tabl. 2. Ova shema sadrži sve faze prethodne sheme, uključujući primjenu faktora sigurnosti, ovaj puta kao neizrazitih veličina. 
Tablica 2. Prilagođena EU shema za određivanje normi - mjesta pripisivanja neizvjesnosti u donošenju norme kao neizrazite veličine

\begin{tabular}{|c|c|}
\hline Raspodjela tvari u okolišu & Mehanizam djelovanja tvari \\
\hline $\begin{array}{c}\text { Procjena količine ulaza tvari } \\
\text { u okoliš }\end{array}$ & $\begin{array}{l}\text { Određivanje odziva (moguće određivanje } \beta \\
\text { kao neizrazite veličine) te obvezno } \tilde{E} \\
\qquad \beta(. .), \tilde{Y}\end{array}$ \\
\hline & $\downarrow$ \\
\hline \multirow[t]{2}{*}{$\downarrow$} & Faktor sigurnosti (kao neizraziti član, $\tilde{F}$ ) \\
\hline & $t$ \\
\hline \multirow{2}{*}{$\begin{array}{l}\text { Modeliranje raspodjele u } \\
\text { okolišu i (predviđena koncen- } \\
\text { tracija u okolišu, prikazano } \\
\text { neizrazitom veličinom } \tilde{X} \text { ) }\end{array}$} & $\begin{array}{l}\text { Vrijednost koncentracije odziva koji ne izazi- } \\
\text { vaju, uz faktor sigurnosti, posljedice (prema } \\
\text { LOEC, NOEC ili } L D_{\text {of }} \text { )te određivanje pripadnih } \\
\text { koncentraciia tvari (neizraziti član) kao }\end{array}$ \\
\hline & $\tilde{X}\left(\widetilde{Y}, \frac{1}{\tilde{F}}\right)$ \\
\hline \multicolumn{2}{|l|}{$\downarrow$} \\
\hline \multicolumn{2}{|l|}{$C B$ analiza } \\
\hline $\begin{array}{r}\text { Definiranje lingvističkih } \\
\text { dono }\end{array}$ & $\begin{array}{l}\text { ijabli normi preko izraza } \operatorname{Int}_{X}\left(\widetilde{X} / \widetilde{X}\left(\widetilde{Y}, \frac{1}{\widetilde{F}}\right)\right) \\
\text { je odluka kao } \mu(X) \leq 1\end{array}$ \\
\hline
\end{tabular}

Ovdje je: Int $x_{x}$ funkcija određivanje intervala norme za X. Pozicioniranje svake norme je, neovisno od primjene faktora sigurnosti, prema V. BARNETT, n. dj. 19., primjena cost-benefit analize (CB analize), tj. analize troška-koristi, koja se temelji na usporedbi vrijednosti troškova aktivnost sprječavanja onečišćenja i koristi poduzimanja takvih aktivnosti. (Ideja CB analize i korištenje finacijskih pokazatelja nije uvođenje tržišnog koncepta, već provedba alokacija sredstava u društvu u kojem su resursi nužno ograničeni).

Način provođenja CB analize za potrebe vrednovanju rezultata praćenja emisija u okoliš, iako se dosta zastupa u legislativi Europske unije, još je uvijek pitanje rasprava. Općenito, relativno se lakše mogu utvrditi troškovi za postizanje usklađenosti s postavljenom normom, ali ne i koristi koje to donosi, pogotovo kada efekti poduzimanja mjera nisu jasno određeni, Peter CALOW, n.dj. 124.-127. U procesu izrade neizrazite norme, prikazanom $u$ tabl. 2., za određivanje mjesta odziva za primjenu CB analize, mogu se koristiti u procesu već određeni intervali, $\operatorname{Int}(X)$, za razliku od determinističkih i statističkih normi, kod kojih se određuje prihvatljivi 
kvocijent rizika. Tako dobivene vrijednosti rezultata CB omogućuju i korekciju postavljenih granica normi, što se posebno ne označava u tabl. 2.

Kako bi se na primjerima pokazala mogućnost primjene neizrazitih normi, $u$ područjima koje sada pokrivaju determinističke i statističke norme iz hrvatskih propisa za emisije u vode (kao i kakvoću voda), pridružuju se neizrazite veličine (lingvističke varijable), sl. 2., sa svojstvom lingvističke varijable (ili neizrazitim skupom) „nepojavljivanja posljedice“ s pripadnom funkcijama udjela $\mu(.$.$) i argu-$ mentima funkcije. Ovdje je potrebno naglasiti da je svojstvo „nepojavljivanja posljedica "izabrano kao ono koje je pojmovno ekvivalentno okolišnoj normi. Oblik koji je izabran za prikaz normi, kao osnovni model, predložen je u Damir RUMENJAK i Siniša ŠTAMBUK, „Fuzzy modelling in air protection“, Geofizički zavod Andrija Mohorovičić Prirodoslovno matematičkog fakulteta Sveučilišta u Zagrebu, Geofizika, 24(2)/2007, 123.-135, za norme za kakvoću zraka.

Kod izbora primjera normi, razmatrani su primjeri iz propisa za emisije otpadnih voda (Pravilnik o graničnim vrijednostima emisija otpadnih voda, Prilog I.), za koje se može primijeniti neizraziti model koji polazi od osnovnog hibridnog modela praćenja (1). To su policiklički aromatski ugljikovodici antracen, naftalen, fluoroanten, benzo(a)piren, koje su u postojećom normama prikazani kao RfC veličine, $\mathrm{u}$ jedinicama koncentracije u rasponu od 0,003 do $0,01 \mathrm{mg} / \mathrm{l}$.

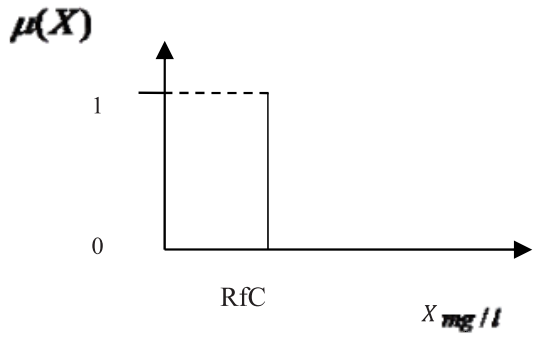

SI. 1. Deterministička norma

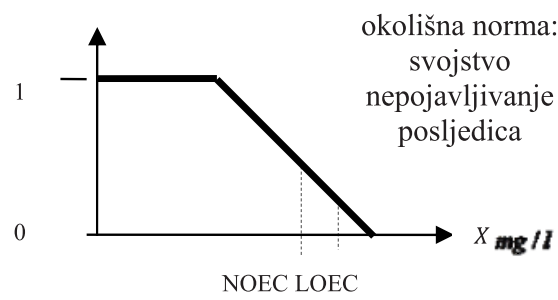

SI. 2 . Neizrazita norma - primjena NOEC i LOEC veličine kod postavljanja norme 


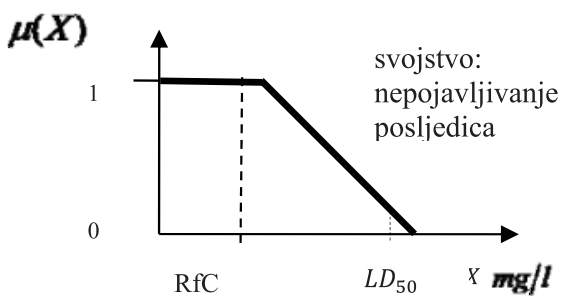

SI. 3 . Neizrazita norma - primjena veličine $\mathrm{LD}_{50}$ kod postavljanja norme te usporedba s RfC

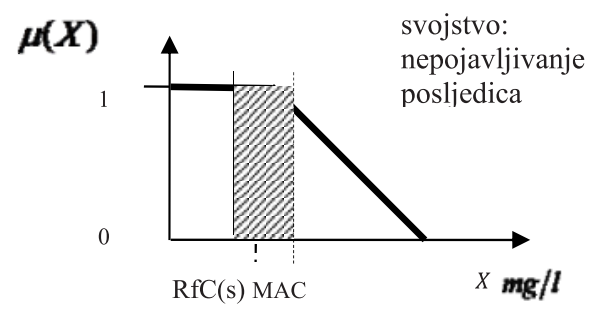

SI. 4 . Statistička norma (RfC) i (MAC) kao dio šire postavljene neizrazite norme

Na sl. 2. i 3. prikazane su neizrazite norme s različitim konceptima referentnih vrijednosti. Dodatno, na sl. 3. prikazan je odnos položaja veličina RfC (deterministička norma) i $L D_{50}$ (koja se koristi kao mjera akutne toksičnosti) prema neizrazitoj normi. (Pri tome položaj RfC, prikazan u odnosu na neizrazitu normu, odražava zapavo težnju postavljanja determinističke norme, u području apsolutne sigurnosti, a ne nužno stvaran položaj.)

Statističke norme, koje su iskazane najčešće kao percentili ili srednje vrijednosti, mogu se prikazati kao dio šire neizrazite norme, kod koje je određena najviše dozvoljena vrijednost koncentracije (MAC) u periodu praćenja (najčešće 1 god.) u odnosu na statistički izraženu referentnu koncentracija, RfC(s), što je prikazano na sl. 4. Primjer koji su razmotreni su iz zakonodavnog okvira EU za površinske vode (standardi kakvoće okoliša), Direktiva 2013/39/EU Europskog parlamenta i Vijeća od 12. kolovoza 2013. o izmjeni direktiva 2000/60/EZ i 2008/105/EZ u odnosu na prioritetne tvari u području vodne politike http://ec.europa.eu/environment/water/water-framework/ index_en.html. (14. travnja 2017.), preneseno Uredbom o izmjenama i dopunama uredbe o standardu kakvoće voda. Listom prioritetnih tvari (zadnja obnova 2016.), iz tih propisa određeni su standardi kakvoće okoliša u odnosu na 45) pojedinačnih tvari ili skupina tvari te ponovna prioritizacija kao revizija postojećih normi (11 pojedinačnih tvari ili skupina tvari). Za potrebe izrade neizrazitih normi razmotreni su: alaklor, atrazin, ugljikov tetraklorid. (Nelinearan slučaj funkcija udjela norme, koji se također može primijeniti, nije posebno prikazan.)

S obzirom na mogućnosti metodološkog aparata neizrazite logike, neizrazita se norma može napisati s više neizrazitih podskupova, tzv. podjela (particija) lingvističkih varijabli, sl. 5., tj. s novim svojstvom lingvističke varijable, kada je između 
krajnjih svojstava, npr. svojstva „nepojavljivanja posljedica “ i svojstva „pojavljivanja posljedica " moguće definirati neko drugo svojstvo koje se može smatrati podskupom skupa osnovne lingvističke varijable. Tako je moguće opisati svojstvo „nepojavljivanje posljedica pod određenim uvjetima“ ili svojstvo „nepojavljivanje određene vrste posljedica" što može povećati razlučivost i područje primjene norme. (Neizvjesnost prikazana neizrazitim veličinama, može se istovremeno opisivati i funkcijama udjela, kao i kroz particije lingvističkih varijabli).

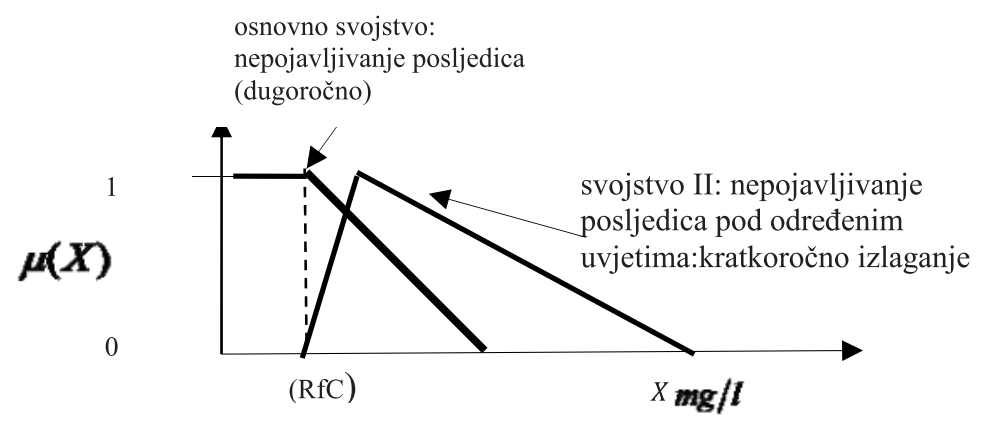

SI. 5. Neizrazita norma s više particija (prvo i drugo svojstvo)

Na sl. 5. prikazan je slučaj jedne takve pretpostavljene norme, u kojoj je drugo svojstvo definirano kao nepojavljivanje posljedica kod kratkoročnog onečišćenja na primjeru iz Uredbe o izmjenama i dopunama uredbe o standardu kakvoće voda, Prilog 5., za tvari 1,2-dikloretan, diklormetan, di(2-etilheksil)ftalat, odnosno za slučajeve gdje je akutna toksičnost niska. (Položaj neizrazitih normi prvog i drugog svojstva prikazan je samo aproksimativno).

Za potrebe osnovnog hibridnog modela praćenja (6), na sl. 6. prikazana je shematski transformacija nesimetrične razdiobe vjerojatnosti kao funkcije varijable praćenja $x \in X$, a koja se dalje može koristiti za neizrazitu pogrješku $\tilde{E}$. 


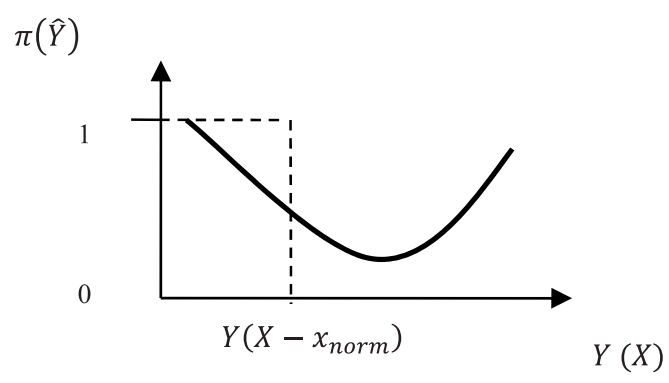

SI. 6. Nesimetrična razdioba pogrješke kao transformacija statističke razdiobe

Pripisivanje vrijednosti funkcija udjela argumentima lingvističke varijable provodi se također definiranim metodama neizrazite logike, Merrie BERGMANN, An Introduction to many-valued and fuzzy logic-Semantic, algebras and derivation systems, Cambridge university press, Cambridge, 2008., 309.-314.

Ono što također treba uzeti u obzir je i velik broj tvari za koje se sve, već i kod klasičnog pristupa, ne primjenjuje shema prikazana u tabl. 1. već drugi pristup, prema P. CALOW, n. dj., 27., kao SAR i PAR (relacije strukture i svojstva tvari), koje se kvantitativno mogu izraziti kroz QSAR i QPAR (Q- kvantitativno) te primjenjujući rezultate određivanje normi na tvari sličnih svojstava i strukture. Primjer odnosa strukture i svojstva su aromatski amino- i nitro- spojevi (npr. benzidin - nitrofen), Ian C. SHAW i John CHADWICK, Principles of environmental toxicology, Taylor and Frances, London, 1998. 50.-52. Takav pristup omogućuje povezivanje skupina tvari sličnih svojstava i struktura istom ili približnim vrijednostima norme.

Ostaje pitanje određivanja $\tilde{X}$, raspodjele tvari u okolišu, koja se definira kao neizrazita veličina, za primjenu u modelu (6). Tu se može poći od tabl. 2., odnosno od tamo definiranih vrijednosti $\tilde{X}$ raspodjele tvari, koje se koriste kod postavljanja normi. Kao opće rješenje tog problema može se dodatno razmotriti primjena lingvističkih transformacija, tj. klase neizrazitih funkcija, kojima se (lingvističko) svojstvo opisano neizrazitom veličinom pretvara transformacijom (tzv. deformacijom horizonta funkcije), E. COX, The fuzzy systems handbook, AP Professional, San Diego, 1999., 218.-223. u novu funkciju koja je odgovarajuće povezana s početnom funkcijom. Te funkcije trebale bi odražavati posebnosti lokacije praćenja, koji je odgovarajuće promijenjen u odnosu na raspodjelu tvari u okolišu, koja je ušla u određivanje norme. Izraz za to je (9):

$$
\tilde{X}_{H}=H(\tilde{X})(9)
$$


gdje je:

$H$ - lingvistička transformacija kojim se deformiraju horizonti neizrazitih funkcija,

$\tilde{X}_{H}$ - raspodjela tvari u okolišu za primjenu u modelu praćenja kroz izraz (6).

Lingvističku transformaciju $(H)$ je moguće definirati i kao kompoziciju različitih funkcija, tj. drugih lingvističkih transformacija.

\section{Primjena neizrazitih normi u praćenju (monitoring) emisija otpadnih voda i stanja voda logičkim metodama}

Osnovni način praćenja temeljem neizrazitih normi je uspoređivanje veličine $x$, dobivene određivanjem iz neizrazitih veličina kao determinantne ili ekvivalentne veličine, s neizrazitom normom s mogućnošću šireg spektra vrednovanja rezultata. Model praćenja je logičko zaključivanje primjenom pravila modus ponens poznatog iz klasične logike, M. BERGMANN, n.dj. 22., a koji se odgovarajuće primjenjuje u neizrazitoj logici (10):

$$
\tilde{x} \in \tilde{X} \rightarrow \tilde{Y}_{i m p}(10),
$$

gdje je:

$\widetilde{Y}_{i m p}$ - neizraziti logički sud dobiven iz neizrazite veličine (odziv).

(Taj model polazi od toga da je neizrazita veličina zapravo logička tvrdnja u neizrazitoj logici). Veličina odziva (neizraziti veličina ili broj) $\tilde{Y}$, iz kojeg se zaključivanjem može dobiti $\tilde{Y}_{i m p}$, računa se izrazom (6). Neizrazita veličina pokazatelja praćenja, prikazana izrazom (8) (ako se do nje dolazi iz vjerojatnosnih razdioba), određuje se zavisno od vrste praćenja (praćenje emisija ili stanja okoliša) i lokacije praćenja, uzimanjem u obzir i ostalih razloga navedenih u ovom radu (izraz (9)).

Implikacija (zaključivanje) prema izrazu (10) se najjednostavnije provodi primjenom logičkog operatora $T$-norme $(T)$, izvedene iz Lukasiewiczeve neizrazite logike, M. BERGMANN, n. dj.179. kao (11) :

$$
\tilde{x} \in \tilde{X} \rightarrow\left(\tilde{Y}_{i m p} \equiv T(\tilde{x}, \tilde{Y})\right)(11)
$$

Osnovni logički operator T-norma je zapravo operator min, budući da je $T(\tilde{x}, \tilde{Y})=\min (\tilde{x}, \tilde{Y})$. (Provođenje aritmetičkih operacija metodama neizrazite logike, potrebno za izraz (6) primjenom ekstenzijskog načela provođenja aritmetičkih operacija u neizrazitoj logici, opisuje se u J. J. BUCKLEY, An introduction to fuzzy logic and fuzzy sets, Physica-Verlag, New York, 2002.) 
Rezultat zaključivanja je veličina $x=\operatorname{def} \tilde{Y}_{i m p}$, koja se dobiva različitim metodama (def) prevođenja neizrazitih veličina u determinantne veličine, kao što su metoda najveće ili najmanje funkcije udjela, metoda centroida (ili metoda centra mase), metoda operatora ( $\alpha$ - rez i $\beta$ - rez), W. STEEB, n. dj. 515.-516. S obzirom na pretpostavljenu primjenu te vrijednosti za usporedbu s normom, može se za determinantnu veličinu $x$ pisati i $x_{N}$.

Izbor implikacijskog modela (drugih normi i ko-normi) može biti samo predmet daljnjih istraživanja, koja ih mogu najbolje potvrditi. Kada se razmatra istovremeno više tvari, odgovarajući, početni logički model mogao bi biti (12):

$$
\tilde{x}_{1} \in \tilde{X}_{1} \wedge \tilde{x}_{2} \in \tilde{X}_{2} \wedge \ldots \tilde{x}_{n} \in \tilde{X}_{n} \rightarrow \tilde{Y}_{i m p z}(12),
$$

s normom zaključivanja $T=\min \left(\tilde{x}_{1}, . \tilde{x}_{n}, \tilde{Y}_{Z}\right)$, gdje je $\bigwedge$ logički operator konjukcije, $\tilde{Y}_{i m p ~ z}$ skup rezultata zaključivanja dobiven iz $\tilde{Y}_{z}$ (zajednički odziv svih varijabli praćenja), $n$ broj tvari (ili skupina tvari) u modelu.

Definiranje skupa $\tilde{Y}_{Z}$ trebalo bi započeti iz svih pojedinačnih funkcija odziva. Neizrazita logika pruža mogućnost uključivanja pojedinačnog odziva tvari u zajedničku funkciju odziva kao $\widetilde{Y}_{z}=f\left(\tilde{Y}_{1}, \tilde{Y}_{2}, \tilde{Y}_{3}, \ldots . . \tilde{Y}_{n}\right)$ s dodatnim pripisivanjem neizvjesnosti kroz ekspertnu procjenu, gdje su $\tilde{Y}_{1} \ldots \tilde{Y}_{n}$ odzivi za pojedine tvari, te s mogućnosti pripisivanja neizvjesnosti za međusobna djelovanja kroz parametar modela $\tilde{\beta}_{i j k . l}$ prije primjene izraza (6). Izraz za određivanje determinantnih veličina tada je $x_{N 1}, x_{N 2}, x_{N 3} \ldots x_{N n}=\operatorname{def} \tilde{Y}_{i m p ~ z}$ u kojem $x_{N n}$ predstavlja determinantnu veličinu za svaku uključenu normu.

Važan razlog za primjenu neizrazitih algoritama za slučajeve praćenja više tvari mogli bi biti sinergijski efekti (pojačano djelovanje) između tvari u okolišu. (Efekat sinergije u okolišu za neke tvari, u odnosu na pojedine, iznosi do 200 do 400 puta, prema C. H. Walker, Organic pollutants, An ecotoxicologial perspectives, Taylor\&Francis, 2001., 59.-60., na primjeru tvari sastojaka insekticida: cipermetrin, karbaril, malation).

\section{Primjena neizrazitih normi u praćenju (monitoring) stanja podzemnih voda}

Pristup određivanju normi za standarde kakvoće okoliša za podzemne vode određeni su zakonodavnim okvirom EU, Direktivom o podzemnim vodama, 2006/118/EZ. U okviru toga provodi se proces normizacije pokazatelja onečišćenja. Proces je dugotrajan, a periodičnim izvješćima europske komisije utvrđuju se prioritet tvari za normizaciju. Poseban propis, koji bi u hrvatsko zakonodavstvo prenio tu direktivu, još nije donijet, http://voda.hr/hr/zakoni-propisi-zastita-voda-vodnogokolisa.html. (15. svibanj 2017.). 
Za praćenje stanja podzemihe voda, dodatno se mogu preporučiti neizraziti modeli za transport tvari. To mogu biti stohastički i deterministički (gaussovski) modeli za onečišćenje podzemnog vodnog okoliša, na kojima je provedena transformacija u neizrazite funkcije, Damir RUMENJAK, Branko SALOPEK i Damir RAJKOVIĆ, Application of environmental engineering models in systems for decision making support, Zbornik radova skupa: „Sustainable development indicators for the mineral industry", Aachen, 2005., 447-457. Modeli su predloženi za predviđanje koncentracija tvari za slučaj utiskivanja otpadne isplačne vode iz industrije nafte $\mathrm{u}$ duboke bušotine, koja sadrži teške metale i mineralna ulja. Kao neizrazita veličina modela predložen je i koeficijent hidrauličke vodljivosti, koji se izvodi iz statističkih razdioba izrazom (8).

\section{ZAKLJUČAK}

Polazeći od osnovnog hibridnog modela praćenja emisija ili stanja onečišćenja okoliša, dosljednom primjenom koncepata neizrazite logike izvedena su rješenja za uvođenje i primjenu neizrazitih normi. Kao oblik neizrazite norme predlaže se lingvistička varijabla sa svojstvom nepojavljivanja posljedica odziva. Svrha takvog pristupa bila bi omogućavanje neizrazitog praćenja, kakvo je prikazano izrazima (6) $\mathrm{i}(10)$.

Određivanje okolišne norme za pojedina onečišćenja neizrazitom logikom može se provoditi, kao i kod određivanja klasičnih normi, prema shemi. Osnovna se shema može dobiti prilagođavanjem postojeće sheme iz EU, pripisivanjem neizvjesnosti u različitim faza izrade normi (tablica 2.). Primjena prilagođenih shema određivanja neizrazitih normi, uz odgovarajuću metodologiju neizrazite logike, omogućila bi da se rezultati za tvari, koje su već normizirane kroz postojeće postupke donošenja, mogu koristiti kod normiziranja primjenom neizrazite logike. Posebno se za to nalaze pogodnim postojeće statističke norme. Također, u početku primjene moglo bi se početi od revizije postojećih normi te korištenjem neizrazitih normi uz klasične, determinističke ili statističke norme, po određenim pravilima. Iako se neizrazitom logikom mogu izvesti matematičko-logički algoritmi za metode praćenja, za primjenu je potrebno još razviti transformacije u neizrazite razdiobe tamo gdje već postoje (ili se primijenjuju) stastičke razdiobe te algoritme za određivanja funkcije udjela za faktore sigurnosti, pripisivanje funkcija udjela raspodjele tvari u okolišu, primjenu implikacijskog modela (drugih normi i ko-normi), određivanje determinantnih veličina iz neizrazitih, lingvističke transformacije i dr.

Ono što se treba uzeti u obzir kod primjene ovog načina praćenja emisija ili stanja okoliša je i razumijevanje svih dionika, pogotovo javnosti, koja sudjeluje $\mathrm{u}$ raznim pitanjima (postupcima) u kojima je predmet primjena normi okoliša. 
Teško je očekivati da će se odmah razumjeti (i prihvatiti) pojam poput „funkcije udjela", kao i način vrednovanja rezultata praćenja koje se opisuje tom normom. Postavljanjem granica vrednovanja rezultata neizrazitom normom otvara se istovremeno i rasprava o klasičnom logičkom paradoksu, sorites paradoks (prema ",sorites“, grč. gomila, hrpa) u logici, tj. pitanju gdje je opravdano postaviti granicu u kontinuiranom slijedu vrijednosti tvrdnji nekog logičkog suda. Iako primjena neizrazite logike, Sthepen READ, Thinking about logic - An introduction to the philosophy of logic, Oxford, Oxford university press, 1995.,173.-202., dosljedno ne rješava taj paradoks u logičkom smislu, ona ga svakako ublažava, proširenjem područja primjene norme, kao i uključivanjem drugih elemenata vrednovanja (npr. rezultati primjene $\mathrm{CB}$ analize na intervalima norme), kojima se, dodatno, vrednovanje rezultata može opravdati.

\section{POPIS LITERATURE}

1. Vic BARNETT i Tony O'HAGAN, Standard setting problems-The statistical approach for handling uncertainty and variation, Chapman\&Hall, London, 1997.

2. David A. WRIGHT i Pamela WELLBOURN, Environmental toxicology, Cambridge university press, Cambridge, 2002.

3. Timothy J. ROSS, Fuzzy logic with engineering applications, Mc. Graw-Hill, 1995.

4. J. B. PARIS, The uncertain reasoner companion - A mathematical perspective, Cambridge university press, New York, 1994.

5. A. K. VERMA, A. SRIVIDIYA, R. S. PRABHU-GAONKAR, Fuzzy-reliability engineering-concepts and applications, Narosa, New Delhi, 2007.

6. Willi-Hans STEEB, The nonlinear workbook, World scientific, New Jersey, 2005.

7. Simone SALICONE, Measurement uncertainity-An approach via the mathematical theory of evidence, Springer, New York, 2007.

8. Robert W. DEMICO i George J. KLIRR, Fuzzy logic in geology, Elsevier academic press, Amsterdam, 2004.

9. http://voda.hr/hr/zakoni-propisi-zastita-voda-vodnog-okolisa.html.

10. Peter CALOW, Controlling environmental risks from chemicals- Principles and practice, John Willey\&Sons, Chichester, 1997.

11. Damir RUMENJAK i Siniša ŠTAMBUK, "Fuzzy modelling in air protection“, Geofizički zavod Andrija Mohorovičić Prirodoslovno matematičkog fakulteta Sveučilišta u Zagrebu, Geofizika, 24(2)/ 2007., 123.-135.

12. http://ec.europa.eu/environment/water/water-framework/index_en.html 
13. Merrie BERGMANN, An introduction to many-valued and fuzzy logic-Semantic, algebras and derivation systems, Cambridge university press, Cambridge, 2008.

14. Ian C. Shaw i John Chadwick, Principles of environmental toxicology, Taylor and Frances, London, 1998.

15. E. COX, The fuzzy systems handbook, AP Professional, San Diego, 1999.

16. J. J. BUCKLEY, An introduction to fuzzy logic and fuzzy sets, Physica-Verlag, New York, 2002.

17. C. H. WALKER, Organic Pollutants, An ecotoxicologial perspectives, Taylor\& Francis, 2001.

18. Damir RUMENJAK, Branko SALOPEK i Damir RAJKOVIĆ, Application of environmental engineering models in systems for decision making support, Zbornik radova skupa "Sustainably development Indicators for the Mineral Industry“, Ahen, 2005., 447-457.

19. Sthepen READ, Thinking about logic- An introduction to the philosophy of logic, Oxford, Oxford university press, 1995.

\section{SAŽETAK}

\section{NORMIZACIJA POKAZATELJA ONEČIŠĆENJA POVRŠINSKIH I PODZEMNIH VODA ALGORITMIMA NEIZRAZITE LOGIKE}

Neizrazita logika (eng. fuzzy logic) je matematičko-logički aparat razvijen za prikazivanje neizvjesnosti u prirodnim, društvenim i tehničkim disciplinama. Pod pojmom neizvjesnosti podrazumijeva se statistička neizvjesnost, kao nepreciznost mjerenja i opažanja, ali i neizvjesnost kod definiranja samih svojstava pojava. Neizrazita logika opisuje neizvjesnost na način koji se može mjeriti sa statističkim (vjerojatnosnim) opisom, a pokazuje se i prikladnijima od njega za sve veći broj slučajeva. Primjena neizrazite logike nameće se stoga kao logičan korak u normizaciji pokazatelja onečišćenja u situacijama praćenja emisija u okoliš, kao i stanja okoliša uzrokovanih onečišćenjem, posebno za vode, gdje je već razvijena metodologija praćenja koja se temelji na statističkim metodama. Ovaj rad stoga daje ocjenu mogućnosti primjene neizrazite logike u praćenju i kontroli pokazatelja onečišćenja okoliša, koja bi se trebala temeljiti na razvoju i primjeni neizrazitih normi, razvijajući pri tome osnovne algoritme. U brojnoj literaturi detaljno se obrazlaže primjena metoda neizrazite logike, što je poslužilo i u ovom radu za razradu potrebnog metodološkog aparata. Nisu zanemareni ni drugi aspekti ovog procesa, kao problem razumijevanja takvih normi od širokog kruga sudionika u postupcima zaštite okoliša, kao što je javnost.

Ključne riječi: hibridni model; pokazatelji onečišćenja; norme; neizvjesnost; neizrazita logika; lingvističke varijable; algoritmi. 


\section{SUMMARY}

\section{STANDARD SETTING FOR POLLUTION INDICATORS OF SURFACE AND UNDERGROUND WATERS BY APPLYING ALGHORITMS OF FUZZY LOGIC}

Fuzzy logic is mathematical and logical apparatus developed for adequate uncertainty description in natural, social and technical disciplines. Under notion of uncertainty statistical uncertainty as imprecision of measurement and monitoring but even in definition of event properties are meant. Fuzzy logic describes uncertainty in the way which could be compared with statistical (probability) description but in increasing number of cases it overcomes it. Research for its application is therefore recognized as logical step in standard setting for pollution indicators for emission monitoring as well as state of environment under pollution pressure, especially for the water environment where probability monitoring is already developed. Primarily, this work gives remark on possibility of applying fuzzy logic in monitoring and control pollution indicators that should be based on developing of fuzzy standards, developing general alghoritms for the purpose. In number of literature application of fuzzy logic is described and it is used here for development of apparatus needed. The aspect of the broader approach, understanding of such standards by the general public involved in, is also not neglected.

Key Words: hybrid model; pollution indicators; standards; uncertainty; fuzzy logic; linguistic variables; alghoritm. 